\title{
Feeding activities of veligers of Nassarius reticulatus and Crepidula fornicata and the use of artificial foods in maintaining cultures of these larvae
}

\author{
G. M. MAPstone \\ University of Reading; Reading, England
}

\begin{abstract}
KURZFASSUNG: Freßaktivitäten der Veliger von Nassarius reticulatus und Crepidula fornicata und die Verwendung von Kunstfutter zur Aufrechterhaltung von Kulturen dieser Larven. Veliger der Prosobranchier Crepidula fornicata (L.) und Nassarius reticulatus (L.) wurden mit Cricosphaera ap. carterae, Dunaliella primolecta oder Exuviaella baltica gefüttert, NassariusLarven außerdem mit Maismehl, Kakao oder dem Fischfutter "Liquifry" (bestehend aus pulverisierten Diatomeen). In Abhängigkeit von der ernährungsphysiologischen Wertigkeit der Nahrung wurde eine unterschiedliche Schwimmaktivität der Veliger festgestellt. Bei guter Futterqualität (Cricosphaera ap. carterae und Dunaliella primolecta für Nassarius reticulatus, Exuviaella baltica für Crepidula fornicata) sammelten sich die Larven, die in zylinderförmigen Versuchsgefäßen bei $14^{\circ} \mathrm{C}$ gehalten wurden, zur Nahrungsaufnahme vorwiegend an der Wasseroberfläche an; zwischenzeitlich, während die Algen verdaut wurden, hielten sie sich bis zu $34 \mathrm{~cm}$ unterhalb der Oberfläche auf. Bei schlechter Futterqualität (Exuviaella baltica für Nassarius reticulatus) oder fehlendem Futterangebot verteilen sich die Veliger in den Versuchsgefäßen und vollführen ungerichtete Schwimmbewegungen. Nach Füllung des Magens mit Algen erfolgte vorerst keine weitere Nahrungsaufnahme; nach 30 min wurden Faeces ausgeschieden. Bei Angebot von Kunstfutter vollzog sich die Nahrungsaufnahme kontinuierlicher; Faeces wurden bereits nach 10-15 min abgegeben. Kunstfutter hat eine schlechtere Wertigkeit als Cricosphaera ap. carterae; diese ist bei Maismehl relativ am besten, bei Kakao am schlechtesten; nach 8-10 Tagen stellten Nassarius-Larven das Wachstum ein. Vorausserzungen für die Aufnahme von Kunstfutter war eine Konzentration von mindestens $20 \times 10^{3}$ Partikeln $/ \mathrm{ml}$.
\end{abstract}

\section{INTRODUCTION}

Prosobranch veligers have been observed gathering food in two ways: food particles in suspension are collected by the velum during swimming, often near the surface of the water, and particles which form a layer on a substratum are swept up by the velum and then directed to the mouth. Ten different algal cultures with cells mainly in suspension have been fed to larvae of Nassarius reticulatus (L.) and Crepidula fornicata (L.); some are more beneficial to growth than others (Pilkington \& FRETTER 1970). The benefit of artificial foods has not been tested. Their particles settle and must be swept up by the velum. In the present work larvae of Nassarius reticulatus were reared for a two-week period on three such artificial foods - cornflour, 
drinking chocolate and Liquifry (an artificial food for newborn fish) and their growth recorded.

Larvae in litre beakers have been observed to have a rhythmical swimming movement, especially obvious when feeding on some species of unicellular algae. A study of such movements has been made on larvae in a column of water containing algal foods.

\section{EXPERIMENTAL CONDITIONS}

Crepidula fornicata and Nassarius reticulatus were chosen for the experiments because batches of newly hatched larvae could be obtained from egg capsules. Before each experiment larvae which had just hatched were transferred to glass filtered seawater and kept at $14^{\circ} \mathrm{C}$ for two days without food, during which time the yolk store was depleted. With artificial foods the bacterial population might be expected to be a hazard, so antibiotics were added. Fresh solutions were made up from powdered antibiotics each time the water and food were renewed. This was necessary since in solution antibiotics deteriorate (MARTINDALE 1967). The concentrations used were those given by WALNE (1958): 50 I.U. penicillin $G$ with 0.05 streptomycin sulphate/l.

The glass columns of water used for observing the larvae feeding in different algal foods were each $115 \mathrm{~cm}$ high and $52 \mathrm{~cm}$ in diameter. Each was marked at $20 \mathrm{~cm}$ intervals to provide reference points for use in estimating the levels at which the larvae occurred. Since it was found that most larvae aggregated in the upper $2 \mathrm{~cm}$ of water an extra reference point was made for this. The algal foods used in the column were Exuviella baltica LoHM., Cricosphaera ap. carterae (BraArud \& FAGERL) BraARUd and Dunaliella primolecta Butch. These species were chosen because they are of differing food value to Nassarius reticulatus and Crepidula fornicata (Pilkington \& Fretter 1969). Larvae grow well with $C$. ap. carterae which will therefore be referred to as a good food for both species. Nassarius reticulatus larvae grow poorly with Exuviaella baltica which will be referred to as a poor food for this species, although Crepidula fornicata grows almost as well with it as with $C$. ap. carterae.

Experiments were carried out at $14^{\circ} \mathrm{C}$. One column was filled with glass filtered seawater only and others with glass filtered seawater to which was added one of the three algal foods at a concentration of $20 \times 10^{3} \mathrm{cells} / \mathrm{ml}$, and two hundred larvae of Nassarius reticulatus or Crepidula fornicata. The top of the column was covered with perforated parafilm to reduce bacterial contamination. The light intensity at the top of the column was 600 lux grading to 130 lux at the base. The experiment was left for $24 \mathrm{~h}$ to allow the larvae to acclimatize to the conditions. After this period the algal cells were conspicuous, owing to their pigment, in the top $2 \mathrm{~cm}$ of the column. The number of larvae in each $20 \mathrm{~cm}$ and surface $2 \mathrm{~cm}$ layers was recorded every $15 \mathrm{~min}$ for a $5-8 \mathrm{~h}$ period and expressed as a percentage of the total number of active larvae. The experiments were repeated with similar conditions using individual larvae, the movements of which were recorded in the same way. 
The rate of upward swimming and downward sinking of the larvae was calculated and the depth to which some larvae sank was recorded. Since artificial foods settle, this poses a different problem which has not been studied.

The artificial foods used were selected from a range of organic foods which were accepted by the larvac in a previous series of experiments (unpublished). These were cornflour and drinking chocolate, with particles of similar size (average diameter for cornflour $12 \mu$, for drinking chocolate $10 \mu$ ), not dissolving in sea water but differing in their constituent food substances and total food content (Tab. 2). The third food was Liquifry which consists of dried diatoms, other plant cells and other particles and is fairly similar to the natural food of the larvae. To measure the growth rates of larvae in artificial foods 30 were placed in litre beakers containing one of the three foods added to $500 \mathrm{ml}$ of seawater treated with antibiotics. The concentrations of the foods were $20 \times 10^{3}$ and $2 \times 10^{3}$ particles/ml for cornflour and drinking chocolate, and $20 \times 10^{3}$ particles $/ \mathrm{ml}$ for Liquifry. Growth of larvae fed on Cricosphaera at $20 \times 10^{3} \mathrm{cells} / \mathrm{ml}$ was also measured to provide a comparison. $500 \mathrm{ml}$ of water gave a depth necessary for the healthy activity of the larvae (FrETTER \& MONTGOMERY 1968). The two concentrations of drinking chocolate and one of Liquifry were replaced by Cricosphaera ap. carterae at a concentration of $20 \times 10^{3}$ cells $/ \mathrm{ml}$ after 7 days. Concentrations of artificial foods above $20 \times 10^{3}$ particles $/ \mathrm{ml}$ were not used in order to avoid excessive bacterial growth. Larvae were kept in each beaker for $12-14$ days at $1^{\circ} \mathrm{C}$ with a constant illumination of approximately 400 lux at water surface; water, antibiotics and food were renewed after 7 days.

Individual larvae of Nassarius reticulatus which had been starved for $12 \mathrm{~h}$ were observed while feeding on natural and artificial foods at approximately $20 \times 10^{3}$ cells or particles/ml under a binocular microscope. The time between the first mouthful and first defecation was noted for five individual larvae in each food and the average figure obtained was termed the "defecation time". Some qualitative analysis of Liquifry was made.

\section{RESULTS}

The histograms of the movements of veligers through various levels in the column while feeding on three different species of alga show that the activity of the larvae differs with the algal food available. With Cricosphaera ap. carterae $50-75 \%$ of Nassarius reticulatus veligers remain feeding at the surface almost continuously, but with Exuviaella baltica only 20-35\% congregate at the surface and the rest are distributed throughout the column (Fig. 1, A \& B). The distribution of larvae in a column with no food (Fig. 1, C) is similar to that in a column where E. baltica is available, although a slightly higher percentage of larvae (30-50\%) remain at the surface. In both these columns larvae were continually migrating through various levels in a random manner. The activity of veligers of Crepidula fornicata feeding on $E$. baltica is different from that of Nassarius reticulatus in the same food and closely resembles the activity of $N$. reticulatus in Cricosphaera ap. carterae. E. baltica, although a poor food for $N$. reticulatus, is a good food for C. fornicata. 
Observations on individual larvae feeding in a column containing Cricosphaera ap. carterae confirm that larvae of both species feed in the top centimetre of water for 1-2 h, then sink $25-35 \mathrm{~cm}$, or occasionally deeper, and without pausing at this depth rise again to the surface. As they rise with the velum fully extended they will
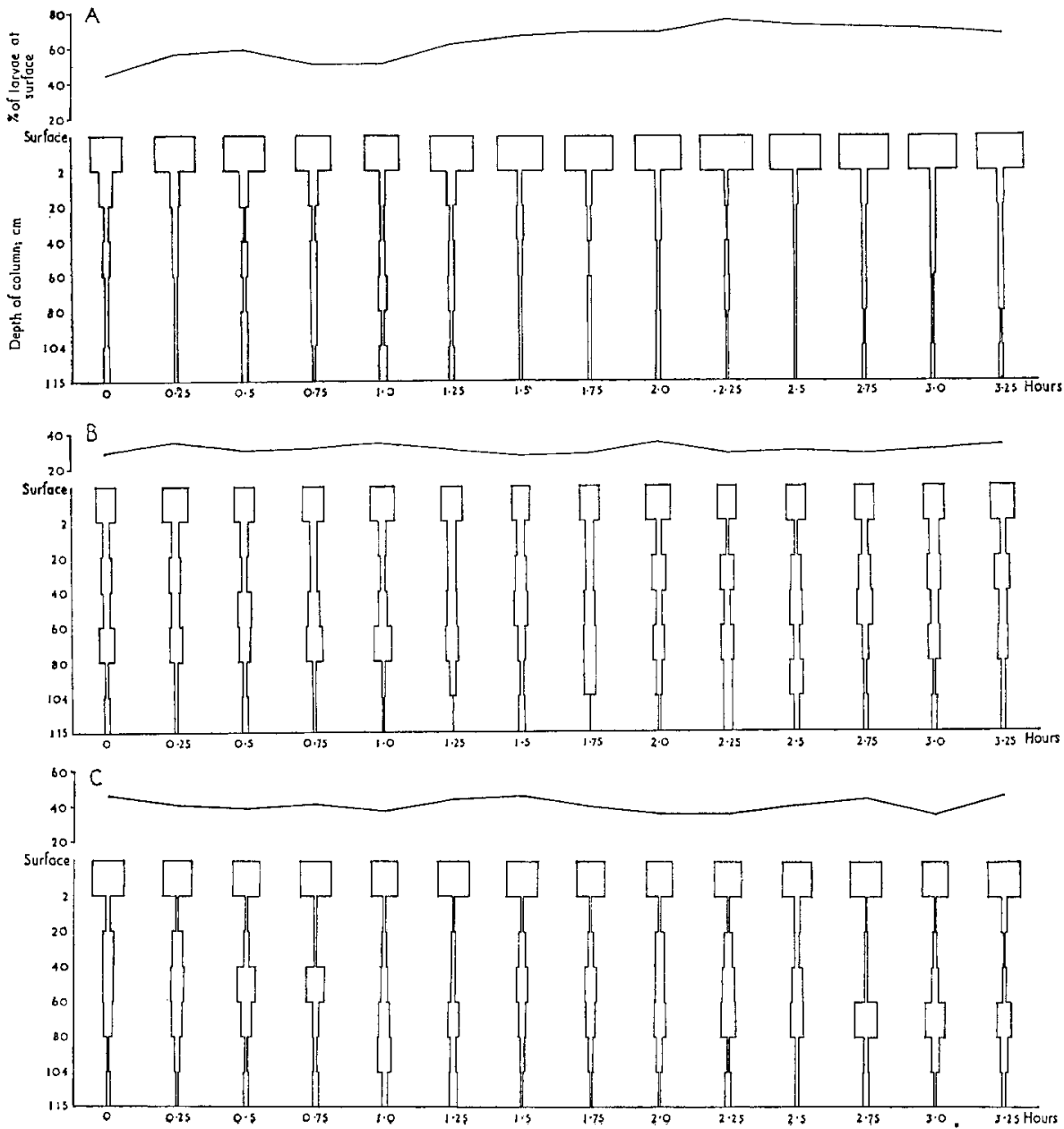

Fig. 1: Histogram to show percentages of Nassarius larvae at different levels in a column of seawater containing (A) Cricospbaera ap. carterae, (B) Exuviaella baltica and (C) no food

ingest a few particles but there is no evidence that food is taken in as they sink. Thirty larvae were observed to take between 20 and $30 \mathrm{~min}$ to make a downward migration; twenty of these larvae dropped to between 26 and $34 \mathrm{~cm}$ and the deepest migration was to $80 \mathrm{~cm}$. While feeding at the surface the larvae were continually rising and sinking in the top centimetre every 5-30 sec; sometimes they swam along the meniscus to gather food. The concentration of algal cells, although originally 
made up to $20 \times 10^{3} \mathrm{cells} / \mathrm{ml}$, increased at the surface after the period of equilibration $(24 \mathrm{~h})$ as the pigmentation of the surface water showed. Haemocytometer counts of C. ap. carterae cells at the end of the experiment gave a concentration of $360 \times 10^{3}$ cells $/ \mathrm{ml}$ at the surface, which decreased with the light gradient to $220 \times 10^{3}$ cells $/ \mathrm{ml}$ at $2 \mathrm{~cm}$ and $150 \times 10^{3}$ cells $/ \mathrm{ml}$ at $10 \mathrm{~cm}$.

Individual larvae in a column without food were observed making continuous migrations in the top $20 \mathrm{~cm}$ without pausing at the surface or the bottom, and occasionally sinking to deeper layers.
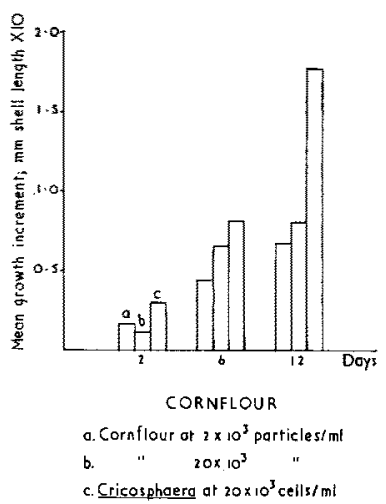
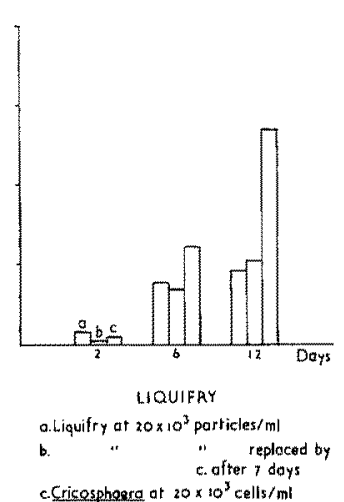

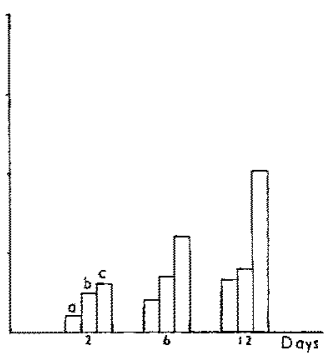

DRINKINC CHOCOLATE a.Drinking Chocolote ot $2 \times 10^{3}$ particles $/ \mathrm{ml}$
reploced by c- ofter 7 doys
$20 \times 10^{3} "$ "

Fig. 2: Histograms showing the comparative growth rates of Nassarius larvae in three artificial foods at two different concentrations

Although the level at which larvae are found in the column is related to the type of food present, the rate at which they rise and sink was found to be fairly similar in all the experiments and does not seem to be dependent upon the presence of food. Larvae sank at a fairly uniform rate which varied between 20 and $34 \mathrm{sec} / \mathrm{cm}$, but were able to swim either directly upwards at a fast rate of $7-8 \mathrm{sec} / \mathrm{cm}$ or by a slower, more circuitous route at a rate similar to the sinking rate, except when feeding on Cricosphaera ap. carterae in which the speed dropped to $40 \mathrm{sec} / \mathrm{cm}$.

All three artificial foods were readily collected by Nassarius reticulatus and retained in the stomach long enough for some digestion to occur. The digestive glands of the larvae become coloured by the food: colourless with cornflour, pale brown with drinking chocolate and pale green with Liquifry. The larvae grew a little in the three artificial foods during the whole period of the experiment, although not so fast as with Cricosphaera ap. carterae and growth ceased after 8-10 days (Fig. 2). Growth was similar in cornflour and in Liquifry (although slightly better in the former) but poor in drinking chocolate. Larvae were most healthy with cornflour and the high mortality rate in drinking chocolate (see Tab. 1) may be related to the development of a bacterial infection.

Growth was slower in the lower concentration of cornflour, and the maximum size reached after 14 days was $399 \mu$, which was $12 \mu$ less than that reached in the higher concentration. The effect of concentration on growth in drinking chocolate 
Table 1

Mortality rates of Nassarius reticulatus larvae in the three growth experiments offering different foods

\begin{tabular}{|c|c|c|c|c|c|c|c|c|c|}
\hline \multirow{3}{*}{ Death after: } & \multicolumn{9}{|c|}{ Number of larvae dead ( 30 larvae per beaker) } \\
\hline & \multicolumn{3}{|c|}{ Cornflour } & \multicolumn{3}{|c|}{ Drinking chocolate } & \multicolumn{3}{|c|}{ Liquifry } \\
\hline & A & B & $\mathrm{C}$ & A & $\mathrm{B}$ & $\mathrm{C}$ & A & $\mathrm{B}$ & $\mathrm{C}$ \\
\hline 2 days & - & - & - & - & 2 & - & - & - & - \\
\hline $4 \mathrm{da}$ & - & - & - & 1 & & 1 & - & - & - \\
\hline 6 days & - & - & 1 & & & 3 & 1 & - & - \\
\hline 8 days & - & - & & & & & & - & - \\
\hline 10 days & - & - & & 2 & & & & - & - \\
\hline 12 days & - & - & & 3 & & & & - & 1 \\
\hline 14 days & - & - & & 4 & 5 & 4 & 5 & 2 & \\
\hline \multicolumn{10}{|c|}{$\begin{array}{l}\text { Beaker A: Artificial food at } 20 \times 10^{3} \text { particles } / \mathrm{ml} \\
\text { Beaker B: Artificial food at } 2 \times 10^{3} \text { particles } / \mathrm{ml}-\text { replaced by Cricosphaera ap. carterae } \\
\text { at } 20 \times 10^{3} \text { cells } / \mathrm{ml} \text { after } 7 \text { days except for cornflour } \\
\text { Beaker C: Cricosphaera ap. carterae at } 20 \times 10^{3} \text { cells } / \mathrm{ml}\end{array}$} \\
\hline
\end{tabular}

Table 2

Defecation times for Nassarius reticulatus offered various foods

\begin{tabular}{|lc|}
\hline Food substance & $\begin{array}{c}\text { Average time from first mouthful } \\
\text { to first defecation (min) }\end{array}$ \\
\hline Dunaliella primolecta & 33.50 \\
Exuviaella baltica & 38.30 \\
Cricosphaera ap. carterae & 23.70 \\
Liquifry & 38.60 \\
Cornflour & 16.80 \\
Drinking chocolate & 11.80 \\
\hline
\end{tabular}

was partly upset by the poor growth in the higher concentration with the result that the maximum shell length reached after 7 days in the lower concentration was only $2 \mu$ less than in the higher concentration. Larvae fed on Liquifry for the first week and Cricosphaera ap. carterae for the second recovered from the poorer food after 3 days and continued to grow at a rate similar to that of larvae feeding on C. ap. carterae.

The defecation times for Nassarius reticulatus feeding on natural and artificial foods can be divided into two groups. Faecal matter from algal cells are passed through the gut in 23-28 min, whereas foods which originate from higher plants and have been processed are passed through in half the time, 12-17 min (Tab. 2).

The results of qualitative tests on Liquifry shown that the following are present: starch grains (iodine test); reducing sugars (Benedict's test); proteins (Million's test). Sudan black revealed no fats. 


\section{DISCUSSION}

Veligers of Nassarius reticulatus and Crepidula fornicata display different types of activity according to the type of food available. In natural algal foods larvae exhibit rhythms of swimming activity associated with feeding and dependent upon the food value of the alga to the particular species of veliger. With artificial foods which settle on a substratum, this normal feeding rhythm is upset and yet the larvae can still obtain sufficient food for growth by sweeping up the particles with the velum. This seems only possible in gastropod veligers other than archaeogastropods in which the velum is so small (CROFTs 1959) that it can have little or no sweeping action. The slow growth rate in the artificial foods can be related not only to their poor food value but also to the fact that the larvae pass the particles rapidly through the stomach and comparatively few are retained and subjected to the digestive juices.

A healthy larva in a good natural food may feed at the surface (where the concentration of algal cells is most dense) for periods of 1 to $3 \mathrm{~h}$, and then spend 20 to 30 min sinking 20 to $35 \mathrm{~cm}$ and returning immediately to the surface. Vertical movements may be related to the light gradient down the column. They were observed in larvae with no food, but these did not pause at the surface as do those which feed. Digestion is continuous from the moment the first food particle is taken in regardless of the swimming activities of the larvae. Defecation has been observed 30 min after the larva has returned to the surface from a downward migration. The actual time taken to make a migration is dependent upon the rising and sinking rates of the larvae. The sinking rate was not apparently influenced by the slight increase in weight caused by a full stomach, since the rate remained the same in all foods and when no food was available. The slow rising rate was also unaffected by the presence of food except by the presence of Cricosphaera ap. carterae. The larvae will ingest a cell or two as they rise and when ingesting $C$. ap. carterae their upward movement is delayed since the cells are larger and more difficult to ingest.

The pattern of activity described above is upset when only a poor food is available to the larva. A much lower percentage of Nassarius reticulatus larvae congregated at the surface in the presence of Exuviaella baltica than in the presence of Cricosphaera ap. carterae or Dunaliella primolecta, and the percentage was even lower than that in the absence of food which suggests that high concentrations of E. baltica (approx. 150-360 cells $/ \mathrm{ml}$ ) may repel the larvae. In the presence of this alga migrations were more numerous further down the column, resembling the random swimming migration of larvae in the absence of food. The vertical movements of veliger larvae recall the activity of other members of the plankton. Their rapid sinking rate enabling them to avoid very dense, surface phytoplankton which may produce an uncongenial environment (HARDY 1936).

Observations under the binocular microscope show that the time taken from the first mouthful to the first defecation is similar for all foods of algal origin and does not seem to be related to the relative food value of the alga to the species of veliger, or to the type of feeding rhythm. In natural foods larvae retain a stomach full of algal cells and then take in only a few cells while digestion takes place, whereas inorganic particles are passed through the gut extremely rapidly, and feeding is con- 
tinuous (Fretter \& MONTgOMery 1968). Bone (1961) found a similar mechanism in Amphioxus lanceolatum in which food particles were filtered slowly and filtering ceased while digestion occurred, whereas inorganic particles were filtered continuously and at a faster rate, and were passed out of the stomach for defecation more rapidly. Similarly, Artemia salina will filter sand particles at X 10 the rate of algal cells at the same concentration (REEVE 1963). In the present experiments feeding on artificial particles was almost continuous and they were passed through the gut at a rate intermediate between that for inorganic particles and that for algal cells; this may be due to the lower food value of the artificial particles to the larvae, as compared with algal cells. It would appear that the stomach can detect the nature of the food, perhaps by chemoreceptors, and be responsible for their rate of passage through the gut. This would explain the longer defecation time for Liquifry compared with cornflour and drinking chocolate, since the former consists primarily of treated algal cells. Such a mechanism would be of advantage to the larva since it would allow a longer time for breakdown of natural foods and thus ensure that maximum nutrient is obtained from the most beneficial foods.

Larvae of Nassarius reticulatus can feed and grow on cornflour and Liquifry for up to a week, but not over a longer period. For the first two days the growth rate was not dissimilar in all three artificial foods and in Cricospbaera ap. carterae, but subsequently it was not as fast nor were the larvae as healthy in the artificial foods and they ceased to grow after 10-12 days. When the artificial foods are compared growth over the first seven days was most vigorous in cornflour, which may be due in part to the nature and food value of the particles. The poor growth in drinking chocolate can be related to the development of a bacterial infection. Liquifry most closely resembles the natural food, although growth was a little slower than in cornflour. The larvae remained healthy for the first week in Liquifry as is shown by their complete recovery when fed on $C$. ap. carterae. They did not thus recover when their first food was drinking chocolate.

Concentration of food particles affects larval growth in foods which are artificial to the larva as it does in natural foods (Pilkington \& Fretter 1970). Growth

Table 3

Total food content Criscosphaera ap. carterae and of two artificial foods

\begin{tabular}{|c|c|c|c|c|}
\hline Food substance & $\begin{array}{l}\text { Protein } \\
\text { (\% dry weight) }\end{array}$ & $\begin{array}{c}\text { Fat } \\
(\% / 0 \text { dry weight })\end{array}$ & $\begin{array}{c}\text { Carbohydrate } \\
\text { (\%/ dry weight) }\end{array}$ & Roughage \\
\hline $\begin{array}{l}\text { Cricospbaera } \\
\text { ap. carterae* }\end{array}$ & 56 & 4.6 & 17.8 & Cellulose \\
\hline Cornflourt: & 0.64 & 0.75 & $\begin{array}{l}98.6 \\
\text { (stard) }\end{array}$ & - \\
\hline $\begin{array}{l}\text { Drinking } \\
\text { docolates: }\end{array}$ & 6.70 & $\begin{array}{c}7.77 \\
\text { (cocoa butter) }\end{array}$ & $\begin{array}{l}81.83 \\
\text { (starch }+ \text { added } \\
\text { disaccs.) }\end{array}$ & $\begin{array}{c}\text { Shell \& stone } \\
\text { cells }\end{array}$ \\
\hline \multicolumn{5}{|c|}{$\begin{array}{l}* \text { Parsons et al. (1961) } \\
* \text { MCCANCE \& WIDDowson (1960) } \\
* \text { Kindly supplied by Messrs. Cadbury, Bournville, Ltd. }\end{array}$} \\
\hline
\end{tabular}


was slower in a concentration of $2 \times 10^{3}$ particles $/ \mathrm{ml}$ of artificial food than in a concentration of $20 \times 10^{3}$ particles $/ \mathrm{ml}$ and suggests that even though particles are less frequently ingested the larvae are still wasteful with them and pass them out rapidly for egestion. If artificial foods are to be used for short term growth of veligers, concentrations of $20 \times 10^{3}$ particles $/ \mathrm{ml}$ or higher are recommended.

The food contents of two of the artificial foods is given in Table 3. Cornflour and drinking chocolate consist almost entirely of carbohydrate and as such provide an unbalanced diet when compared with the food content of Cricospbaera ap. carterae. Figures are not available for Liquifry but the qualitative tests have shown the presence of proteins and carbohydrates, including some starch grains. It is probable that since Liquifry consists of pulverised diatoms, other plant cells, starch grains and other ingredients it would provide a more balanced diet, although the diatom frustules comprise a high percentage of indigestible material and cellulose walls. It is also treated in the larval gut in a similar way to algal cells in that it is retained in the stomach for digestion. Drinking chocolate contains protein granules, cocoa butter and roughage as well as starch, and, although some of these constituents may be of use to the veliger, bacterial action counteracted any value that the food may have.

Cricosphaera ap. carterae is a complete food for veliger larvae and produces healthy growth to metamorphosis in Nassarius reticulatus (Pilkington \& FretTer 1970). The present study reveals that an artificial food such as cornflour or Liquifry, although it lacks essential micronutrients for long term growth, can be used to maintain cultures of larvae over short periods.

\section{SUMMARY}

1. Veligers of Crepidula fornicata (L.) and Nassarius reticulatus (L.) were fed on the algae Cricosphaera ap. carterae, Dunaliella primolecta and Exuviaella baltica (each at a concentration of $20 \times 10^{3} \mathrm{cells} / \mathrm{ml}$ ) in suspension in columns of seawater (height $115 \mathrm{~cm}$ ), and their movements observed over a 5 to $8 \mathrm{~h}$ period.

2. Nassarius reticulatus larvae were also fed on three artificial foods (cornflour, drinking chocolate and Liquifry - consisting mainly of pulverised diatoms) which settle to form a layer on a substratum and their growth was measured over a 12-14 day period.

3. The time taken from the first mouthful to the first defecation was recorded for larvae feeding on all six foods.

4. There are two patterns of swimming activity associated with feeding on algae in suspension dependent upon the food value of the alga to the particular species of veliger.

5. With a good food (Cricosphaera ap. carterae and Dunaliella primolecta for Nassarius reticulatus, Exuvialla baltica for Crepidula fornicata) all larvae congregate at the surface to feed, dropping intermittently 26 to $34 \mathrm{~cm}$ while digestion continues. The first defecation occurs about 30 min after feeding begins.

6. With a poor food (Exuviaella baltica for Nassarius reticulatus) and without food, larvae are distributed more evenly throughout the water column and make random swimming movements. 
7. When no food is present in the column two rising rates are evident $20-30 \mathrm{sec} / \mathrm{cm}$ and $7-8 \mathrm{sec} / \mathrm{cm}$, and one sinking rate $20-34 \mathrm{sec} / \mathrm{cm}$. This also holds in the presence of bad and good foods except in Cricosphaera ap. carterae in which larvae rose more slowly $(40 \mathrm{sec} / \mathrm{cm})$.

8. The treatment of the six foods in the gut differs: when the stomach is full, feeding more or less ceases in case of algal foods and faeces are formed after $30 \mathrm{~min}$; feeding is more continuous with artifical foods only some particles being retained for digestion and faeces are produced after 10-15 min.

9. Some growth of Nassarius reticulatus occurs in artificial foods, although it is less than in Cricosphaera ap. carterae, and ceases after 8-10 days. Growth over the first seven days is most vigorous in cornflour, good in Liquifry but poor in drinking chocolate owing to bacterial contamination. Growth resumed when larvae fed on Liquifry were given Cricosphaera ap. carterae indicating that they remained healthy.

10. The concentration of cornflour and Liquifry is a critical factor. At $2 \times 10^{3}$ particles $/ \mathrm{ml}$ growth was poor, probably as a result of starvation, and a concentration of $20 \times 10^{3}$ particles $/ \mathrm{ml}$ or higher is recommended.

11. The food value of an artificial food affects growth. Cornflour and drinking chocolate have a very high carbohydrate content giving an unbalanced diet. Liquifry has a more balanced food content but it contains large amounts of indigestible material which must reduce the food value.

12. Artifical foods can be used to maintain cultures of larvae over a short period, but not for long term growth as they lack essential micronutrients present in natural algal foods.

Acknowledgements. This work was carried out at the Plymouth Laboratory and was supported by a Research Studentship from the Natural Environment Research Council. I wish to express thanks to my supervisor Dr. V. FretTer for her untiring help and advice, to Dr. M. PARke who supplied the algal cultures, to Mr. J. GReEN who obtained the egg capsules and especially to the Director, Dr. J. E. SMITH, F.R.S., for providing space and facilities.

\section{LITERATURE CITED}

BONE, Q., 1961. The organization of the strial nervous system of Ampbioxus (Branchiostoma lanceolatum Pallas). Phil. Trans. R. Soc. (B) 243, 241-269.

CROFTs, D. R., 1955. Muscle morphogenesis in primitive gastropods and its relation to torsion. Proc. zool. Soc. Lond. 125, 711-750.

Fretter, V. \& Montgomery, M. C., 1968. The treatment of food by prosobranch veligers. J. mar. biol. Ass. U.K. 48, 499-520.

Hardy, A. C., 1936. Plankton ecology and the hypothesis of animal exclusion. Proc. Linn. Soc. Lond. 148 (2), 64-70.

McCance, R. A. \& Widdowson, E. M., 1960. The composition of foods. Spec. Rep. Ser. med. Res. Coun. 297, 1-252.

Martindale, W., 1967. Antibiotica. In: Todd, R.G.: Extra Pharmacopoeia. Pharmaceutical Press, London, $1804 \mathrm{pp}$.

Parsons, T. R., Stephens, K. \& Strickland, J. D. H., 1961. On the chemical composition of 11 species of marine phytoplankters. J. Fish. Res. Bd. Can. 18, 1001-1016. 
Pilkington, M. C. \& FretTer, V., 1970. Some factors affecting the growth of prosobranch veligers. Helgoländer wiss. Meeresunters. 20, 576-593.

ReEve, M. R., 1963. The filter feeding of Artemia. 1-3. J. exp. Biol. 40, 195-221.

WALNE, P. R., 1958. The importance of bacteria in laboratory experiments on rearing the larvae of Ostrea edulis (L.). J. mar. biol. Ass. U.K. 37, 415-425.

Author's address: GrLtran M. Mapstone

University of Reading

Department of Zoology

Reading, Berkshire, England 